\title{
MANAGEMENT TOOLS WORLDWIDE COMPARED TO OLOMOUC REGION, UTILIZATION AND TRENDS IN INDUSTRIAL COMPANIES
}

\author{
${ }^{1}$ Adam PAWLICZEK, ${ }^{2}$ Pavel KOLOŠ, ${ }^{3}$ Štefan KOLUMBER \\ ${ }^{1}$ Moravian University College Olomouc \& University of Economics, Prague, Czech Republic, EU, \\ adam.pawliczek@mvso.cz \\ ${ }^{2}$ VSB - Technical University of Ostrava, Ostrava, Czech Republic, EU, \\ pavel.kolos.st@vsb.cz \\ ${ }^{3}$ Moravian University College Olomouc, Prague, Czech Republic, EU, \\ stefan.kolumber@mvso.cz
}

https://doi.org/10.37904/metal.2020.3666

\begin{abstract}
The aim of the paper is to analyze and describe recent application of management tools in the enterprises worldwide including their utilization and trends in timeline compared to industrial companies in Olomouc region, Czech Republic. The main data source for presented paper is the research performed by Bain \& Company, Inc. (BC) which concentrates on surveying of management tools in companies worldwide since the year 1993, while primary research was performed by authors in companies that produces and customizes metal parts for automotive and aerospace industry. The motivation behind this paper is based on effort to make students and academics in management focus on most recent and powerful management tools to boost successful business. The latest survey of $B C$ has more than 14,700 respondents from more than 70 countries in North America, Europe, Asia, Africa, the Middle East and Latin America, and is probably the most comprehensive systematic long-term study in the world. The management tools in the top ten list vary in time, but four of them remain since 1993 (however some of them temporarily disappeared): Benchmarking, Customer satisfaction, Total quality management and Vision and mission statement.
\end{abstract}

Keywords: Management tools, industrial companies, trends

\section{INTRODUCTION}

The relevance of the topic is illustrated by publication and citation numbers of Web of Science. For the keywords "management" AND "tools" in the title, 8,201 publications with 59,321 citations without self-citations and h-index 90 were found on 27th January 2020. The annual number of citations has exceeded 7,000 in the past years. One of the biggest organizations engaging in management tools utilization in enterprises is Bain \& Company (BC).

BC advises clients on strategy, operations, technology, organization, private equity and mergers and acquisitions. They develop practical, customized insights that clients act on and transfer skills that make change stick. Founded in 1973, BC has 55 offices in 36 countries, and their deep expertise and client roster cross every industry and economic sector [1].

\subsection{Research of the current state of knowledge}

Every company focuses on maximization of efficiency and sustainability. However, these two terms are often difficult to quantify and formulate. There are different approaches to support these goals. One of the areas that can positively affect the functioning of the company are management tools [2]. 
Literature searches often focus on the relationship between strategic planning and the real performance of a firm, but only few studies describe the usefulness of applying management tools $[3,4,5]$.

Existing studies have shown that the proper use of management tools and techniques positively affect organizational performance (Iseri Say a kol., 2006; Al-Khadash \& Feridun, 2006; Indiatsy a kol., 2014). The performance and quality of the work is being perceived as more effective and beneficial. Together with work instructions and guidelines, employees appreciate the tools that help with processes maintenance and improvements [6].

Management tools are one of the basic elements for managing the company's performance. More and more, it is important to collect the right data for the necessary analyzes so that the right decisions can be made. An appropriate set of tools plays a crucial role in the whole cycle of the company and it is very important for the natural and sustainable development of the organization $[7,8]$.

Dynamic development and often increased competition force companies to constantly improve all processes to maintain competitiveness in today's market. This is done by simple and quick-to-apply tools, as well as complex and complicated tools requiring special software or IT equipment. The combination of both variants creates a comprehensive set of management tools that serve to increase performance in the company and often allows you to find innovative solutions $[9,10,11]$.

The basis of every company is a vison and a plan. A common cause of failure is the application of inappropriate tools or their incorrect use [12,13]. For this reason, companies also need to focus on training in management tools, whether they are employees working on internal process or sales specialist or buyers who build and maintain relationships with customers or suppliers [14,15].

The trend and probably a key area of using management tools is digitization. It allows you to combine all the needs in one place with the application of the necessary tools and visualizations to satisfy all the parts of the company [16].

\subsection{Theoretical background - Management Tools}

Academics define an immense number of management methods, tools, techniques or indicators that were developed to help the companies achieve the highest efficiency and the best performance. Many of this method are difficult to establish, some of them could bring the company very tangible outputs, some have less-tangible outcomes. Contemporary companies are employing more management methods, but they appear to be finding them less effective [1, 4]. Here follows the list of top ten popular management tools:

- $\quad$ Strategic Planning,

- $\quad$ Customer Relationship Management (CRM),

- Benchmarking,

- $\quad$ Advanced Analytics (Big Data Analytics),

- Supply Chain Management,

- Change Management Programs,

- Total Quality Management (TQM,

- Digital Transformation,

- Mission and Vision Statements.

\section{THE METHODOLOGY OF THE PAPER}

Goal of the paper has been set to analyze and describe recent application of management tools in the enterprises worldwide including their utilization and trends in timeline (2006 to 2019). Comparison to primary 
data from industrial companies in Olomouc region of Czech Republic (2019) is also presented. Three research questions were formulated:

1) Are the most popular management tools varying in time?

2) Do exist some management tools which are stable in the top ten group for decades?

3) Are there similar results in utilization of management tools worldwide and in industrial companies in the Czech Republic?

The secondary data obtained by $\mathrm{BC}$ and primary data collected by $\mathrm{MBCO}$ students were used for evaluation of research questions. Linear regression including equations and coefficients of reliability were calculated.

\subsection{Data Collection}

The primary data were collected in year 2019 in the Olomouc region of the Czech Republic. Totally were collected 123 questionnaires, but 7 were rejected due to incompleteness. The structure of primary sample was following:

- Legal status: $49 \%$ limited liability companies, $31 \%$ self-employed and $20 \%$ joint stock companies.

- $\quad$ Size regarding the number of employees: $33 \%$ micro (0 to 10), $35 \%$ small (11 to 50), $19 \%$ medium ( 51 to 250 ) and $13 \%$ big (more than 250 ) companies.

- The industrial enterprises were established since 1950 to 2013 year.

Since 1993, BC has surveyed executives around the world about the management tools they use and how effectively those tools have performed. The objective is to provide managers with information they need to identify and integrate tools that will improve business performance results, and to understand how global executives view their strategic challenges and priorities. They focus on 25 tools, honing the list each year. To be included in their survey, a tool needs to be relevant to senior management, topical and measurable. By tracking the tools companies are using, under what circumstances and how satisfied managers are with the results, they have helped them make better choices in selecting, implementing and integrating the tools to improve their performance. With this, their 16th (in 2017) survey, they now have more than 14,700 respondents from more than 70 countries in North America, Europe, Asia, Africa, the Middle East and Latin America, and they can systematically trace the effectiveness of management tools over the years. As part of their survey, they also ask executives for their opinions on a range of important business issues. As a result, they can track and report on changing management priorities [1].

\section{RESULTS OF THE SURVEY}

Chapter present most important findings of management tools application in the world and Olomouc Region of the Czech Republic. Results are characterized by Table 1 and Figure 1 (world) including linear regression and trends and Figure 2 (Industrial Companies in Olomouc region) - Pareto chart.

\subsection{Application of Management Tools in the World and its Trends}

Table 1 characterizes top ten of utilized management tools in the world companies in years 2006, 2010, 2012, 2014 and 2019.

There is well visible that some management tools lose their popularity (Business Process Reengineering, Scenario and Contingency Planning, Knowledge Management) while some gain popularity (Advanced Analytics, SCM, TQM, Digital Transformation) while still others stay in the top ten ladders for long period of time (Strategic Planning, CRM, Benchmarking, Mission and Vision Statement). 
Table 1 Management Tools utilization in the world companies (own processing)

\begin{tabular}{|c|c|c|c|c|c|}
\hline Place & 2006 & 2010 & 2012 & 2014 & 2019 \\
\hline 1 & Strategic Planning & Benchmarking & Strategic Planning & CRM & Strategic Planning \\
\hline 2 & CRM & Strategic Planning & CRM & Benchmarking & CRM \\
\hline 3 & $\begin{array}{c}\text { Customer } \\
\text { Segmentation }\end{array}$ & $\begin{array}{l}\text { Mission and Vision } \\
\text { Statements }\end{array}$ & $\begin{array}{c}\text { Employee } \\
\text { Engagement } \\
\text { Surveys }\end{array}$ & $\begin{array}{c}\text { Employee } \\
\text { Engagement } \\
\text { Surveys } \\
\end{array}$ & Benchmarking \\
\hline 4 & Benchmarking & CRM & Benchmarking & Strategic Planning & $\begin{array}{c}\text { Advanced } \\
\text { Analytics }\end{array}$ \\
\hline 5 & $\begin{array}{c}\text { Mission and Vision } \\
\text { Statements }\end{array}$ & Outsourcing & $\begin{array}{l}\text { Balanced } \\
\text { Scorecard }\end{array}$ & Outsourcing & $\begin{array}{l}\text { Supply Chain } \\
\text { Management }\end{array}$ \\
\hline 6 & $\begin{array}{c}\text { Core } \\
\text { Competencies }\end{array}$ & $\begin{array}{l}\text { Balanced } \\
\text { Scorecard }\end{array}$ & $\begin{array}{c}\text { Core } \\
\text { Competencies }\end{array}$ & $\begin{array}{l}\text { Balanced } \\
\text { Scorecard }\end{array}$ & $\begin{array}{c}\text { Customer } \\
\text { Satisfaction }\end{array}$ \\
\hline 7 & Outsourcing & $\begin{array}{c}\text { Change } \\
\text { Management }\end{array}$ & Outsourcing & $\begin{array}{l}\text { Mission and Vision } \\
\text { Statements }\end{array}$ & $\begin{array}{c}\text { Change } \\
\text { Management }\end{array}$ \\
\hline 8 & $\begin{array}{c}\text { Business Process } \\
\text { Reengineering }\end{array}$ & $\begin{array}{c}\text { Core } \\
\text { Competencies }\end{array}$ & $\begin{array}{c}\text { Change } \\
\text { Management }\end{array}$ & $\begin{array}{l}\text { Supply Chain } \\
\text { Management }\end{array}$ & TQM \\
\hline 9 & $\begin{array}{c}\text { Scenario and } \\
\text { Contingency } \\
\text { Planning }\end{array}$ & Strategic Alliances & $\begin{array}{l}\text { Supply Chain } \\
\text { Management }\end{array}$ & $\begin{array}{c}\text { Change } \\
\text { Management }\end{array}$ & $\begin{array}{c}\text { Digital } \\
\text { Transformation }\end{array}$ \\
\hline 10 & $\begin{array}{l}\text { Knowledge } \\
\text { Management }\end{array}$ & $\begin{array}{c}\text { Customer } \\
\text { Segmentation }\end{array}$ & $\begin{array}{l}\text { Mission and Vision } \\
\text { Statements }\end{array}$ & $\begin{array}{c}\text { Customer } \\
\text { Segmentation }\end{array}$ & $\begin{array}{l}\text { Mission and Vision } \\
\text { Statements }\end{array}$ \\
\hline
\end{tabular}

Figure 1 underlines findings from Table 1 with more illustrative way including linear trend lines with their equations and coefficients of reliability. $X$ axe represents timeline, $Y$ axe represents ranking of the management tool. Directions of linear trends characterize if popularity of the management tool increase (negative value), decrease (positive value) and how much (absolute value). Most promising are Supply Chain Management $(-0,8158)$, CRM $(-0,0843)$ and Benchmarking $(-0,061)$ whose popularity grows in time. Mast falling in popularity are Mission and Vision Statement $(0,5087)$ and Strategic Planning $(0,0698)$. Most stable is Change Management $(0,0093)$. There is necessary to mention, that linear trend is calculated only if at least three time-values are present.

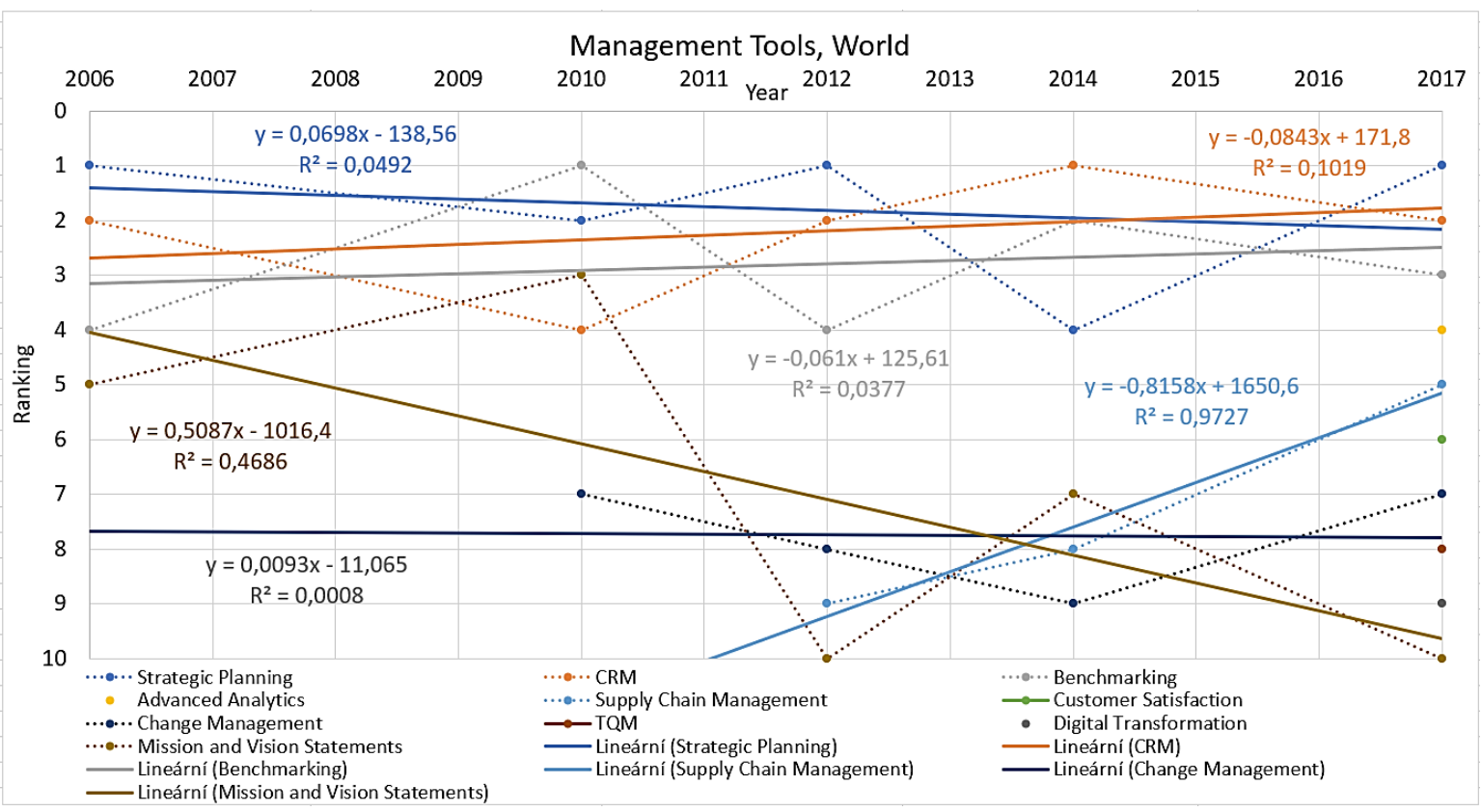

Figure 1 Management Tools in the World (own processing) 


\subsection{Application of Management Tools in the Industrial Companies in the Czech Republic, Olomouc region}

Following Figure 2 illustrates popularity of management tools in surveyed industrial companies group in Olomouc region of the Czech Republic in the year 2019. Utilization of 24 management tools were evaluated. Overall knowledge of management tools is very small. Only three management tools (strategic document, SWOT analysis and SMART principles) are recognized by more than $20 \%$ of surveyed enterprises and seven (+ EVA indicator, Total Quality Management, Key Performance Indicators and Management by Objectives) over $10 \%$ of enterprises.

$64 \%$ of surveyed enterprises have prepared detailed or concise written strategic document (business plan). SWOT analysis recognized by $48 \%$ of enterprises is long-term best-known strategic analytic technique and SMART principles (24\%) are related to setting of goals. Economic Value-Added indicator observe $14 \%$ of enterprises and for Total Quality struggles also $14 \%$ of enterprises. KPI and MBI are closely interconnected and are aimed by $12 \%$ resp $10 \%$ of enterprises.

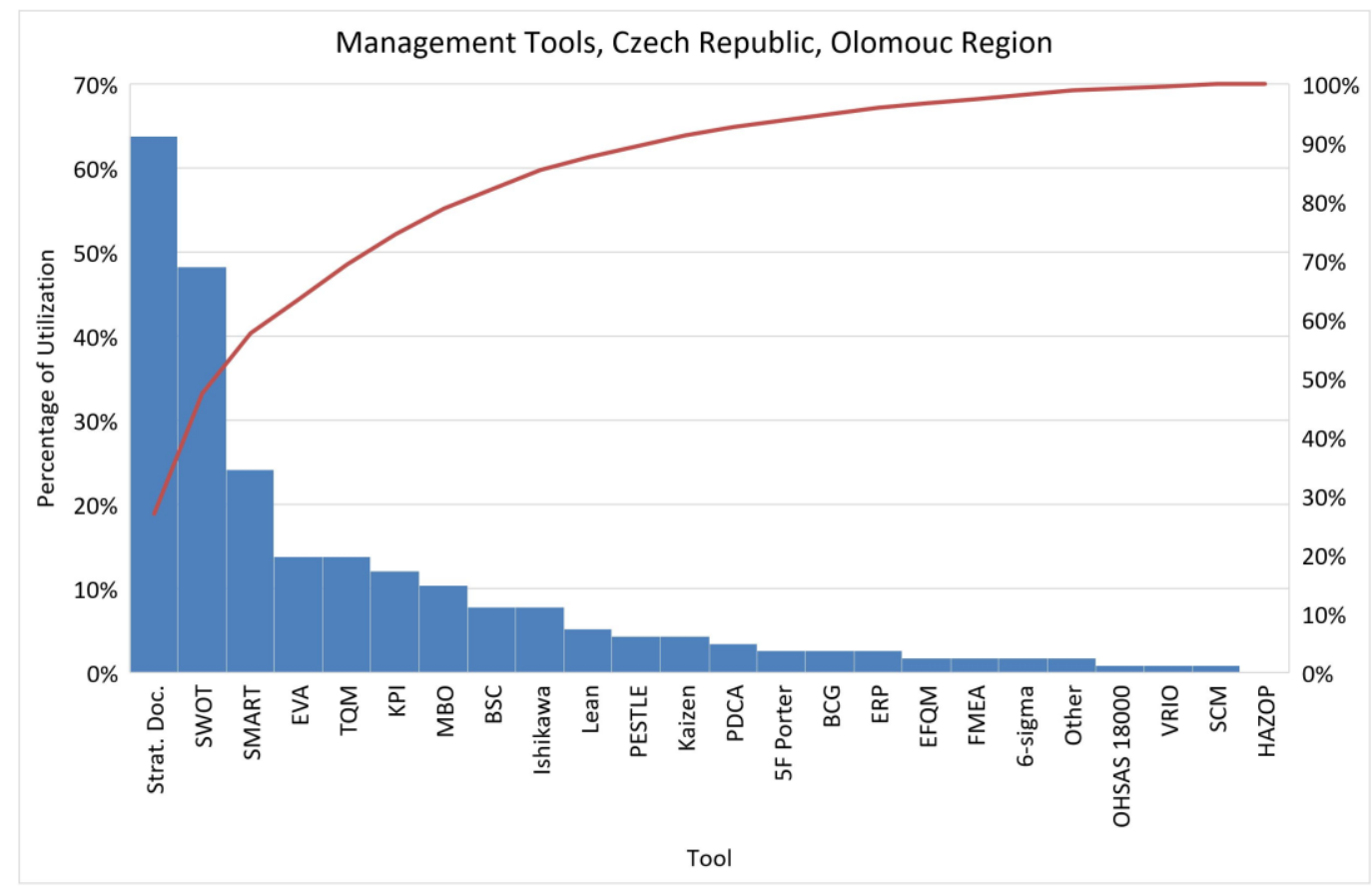

Figure 2 Management Tools in the Industrial Companies in the Czech Republic, Olomouc region, year 2019 (own processing)

\section{DISCUSSION AND CONCLUSION}

We can say that the goal of the paper to analyze and describe recent application of management tools in the enterprises worldwide including their utilization and trend in timeline and compare it to situation in industrial companies in Olomouc region of the Czech Republic was fulfilled. The research questions were answered:

1) Management tools in the top ten ladders are varying in time. Three management tools are in top ten 2019 new, three management tools from top ten 2006 disappeared till the 2010 and more three disappeared till 2019.

2) Four management tools however are stable in the top ten group for all 11 years.

3) There are some similar results in application of management tools worldwide and in the Czech Republic related to two tools: Strategic planning, resp. strategic document as well as TQM are among the most popular worldwide and in the industrial companies in Olomouc region too. 
The research goals were fulfilled with the data of primary research and BC. Most important added value of the paper is comparison of utilization of management tools in world and Olomouc region conditions and accentuation which management tools have increasing or decreasing tendency in time and which are most stable. The overall world winner of management tool stability is Mission and Vision Statement which endures since 1993 however its trend in popularity is weakening. World and regional star is Strategic Document/ Planning. Both tools are closely interconnected.

The sample and data of $\mathrm{BC}$ research are comprehensive reliable and huge. In other hand the Olomouc region sample is focused mainly on micro and small industrial enterprises. Future research could be aimed more to bigger industrial companies in the whole Czech Republic.

\section{REFERENCES}

[1] RIGBY, D.K. Management Tools 2017, An executive's guide, Boston: Bain \& Company, Inc., 2017. ISBN: 09656059-7-3.

[2] SOKOLIC, D., MRAK, M.K., VRETENAR, N. Business Management Tools and Firm Performance. 4th International Multidisciplinary Scientific Conference on Social Sciences and Arts SGEM. Bulgaria: Albena Co., 2017, pp. 139-146.

[3] AFONINA, A. Strategic Management Tools and Techniques and Organizational Performance: Findings from the Czech Republic. Journal of Competitiveness. 2015, vol. 7, no. 3, pp. 19-36.

[4] PAWLICZEK, A., NAVRATILOVÁ, D. Utilization of Modern Management Methods in Moravian Companies Advanced Stage Research Results. 1st International Conference on Lifelong Learning and Leadership for All Peer-Reviewed Conference Proceedings, Olomouc: 2015.

[5] CHLOPECKÝ, J., PAWLICZEK, A., VILAMOVÁ, Š., MORAVEC, L., HUBÁČEK, J., AMEIR, O. Strategic risk management of an enterprise depending on external conditions In 18th International Multidisciplinary Scientific GeoConference Surveying Geology and Mining Ecology Management, SGEM 2018, 18 (1.3), pp. 855-861.

[6] FERGUSON, L.K., REIO, T. Human Resource Managerial System and Firm Performance. Journal of Management Development. 2010, vol. 29, no. 5, pp. 471-494.

[7] ALDEHAYYAT, J., KHATTAB, A., ANCHOR, J. The Use of Strategic Planning Tools and Techniques by Hotel in Jordan. Management Research Review. 2011, vol. 34, no. 4, pp. 477-490.

[8] BRIŠ, P., KOLÁŘOVÁ, E., KOLUMBER, Š. Enforcing BSC And QMS Tools During The Qualitative Corporation Management. In Proceedings of the 8th International Scientific Conference Finance and Performance of Firms in Science, Education and Practice 2017, pp. 110-124 Fakulta managementu a ekonomiky, UTB ve Zlíně.

[9] EFENDIOGLU, A., ARABALUT, A. Impact of Strategic Planning on Financial Performance of Companies in Turkey. International Journal of Business and Management. 2010, vol. 5, no. 4, pp. 3-12.

[10] FRIEDL, P., BILOSLAVO, R. Association of Management Tools with the Financial Performance of Companies: The Example of the Slovenian Construction Sector. Journal of Managing Global Transition. 2009, vol. 7, no. 4, pp. 383-402.

[11] RYLKOVÁ, Z., ŠEBESTOVÁ, J. Managerial Decision on Strategic Objectives in Global Environment. SHS Web of Conferences [online]. 2020, 74 [cit. 2020-06-22]. DOI: 10.1051/shsconf/20207401029. ISSN 2261-2424.

[12] ISERI-SAY, A., TOKER, A., KANTUR, D. Do Popular Management Techniques Improve Performance?. Journal of Management Development. 2008, vol. 27, no. 7, pp. 660-677.

[13] ZIMMERMANNOVÁ, J., PAWLICZEK, A., ČERMÁK, P. Public support of solar electricity and its impact on households-prosumers. Organizacija, 2018, 51(1), 4-19.

[14] SIN, L.Y.M, TSE, A.C.B, YIM, F.K.H. CRM: Conceptualization and Scale Development. European Journal of Marketing. 2005, vol. 39, no. 11/12, pp. 1264-1290.

[15] SCHIERHOLZ, R. KOLBE, L.M, BRENNER, W. Mobilizing Customer Relationship Management: A Journey from Strategy to System Design. Business Process Management Journal. 2007, vol. 13, no. 6, pp. 832-833.

[16] WILLIAMS, P., NAUMANN, E. Customer Satisfaction and Business Performance: A Firm Level Analysis. Journal of Services Marketing. 2011, vol. 25, no. 1, pp. 20-32. 